\title{
BMI Indicators in Children with Intellectual Disabilities
}

\author{
Jitka Králíková, Hana Válková \\ Faculty of Sports Studies, Masaryk University, Brno
}

\begin{abstract}
Currently, obesity in people with intellectual disabilities, whose daily lives are to a certain degree affected by their impairment, is increasingly becoming the focal point of attention. However, there is a lack of scientific data for children with intellectual disabilities.

The aim of this research is to determine whether children with intellectual disabilities are prone to obesity, whether obesity is gender-and age-specific, what is the distribution of intellectual disabilities in boys and girls and whether any level of intellectual disability shows a higher proclivity to obesity. The method employed was comparative and qualitative research approached deductively. For the collection of BMI indicators, InBody analyser was used to measure the data of 49 children attending two special needs primary schools.

The findings of the research show that the BMI values of more than a half of children with intellectual disabilities in all assessed groups is within norm. Boys are estimated to have a lower BMI in middle adolescence than in early adolescence and school age. Girls are highly likely to have a higher BMI in late adolescence than in middle and early adolescence. In boys, obesity is associated with early adolescence and mild to moderate level of intellectual disability, whereas in girls with middle adolescence and mild level of intellectual disability.
\end{abstract}

Key words: children with intellectual disabilities, special elementary school, the BMI indicator, levels of intellectual disabilities, obesity.

\section{INTRODUCTION}

Childhood obesity is considered one of the most pressing public health issues of today. Its prevalence is continuously rising. Unfortunately, no consensus as to how this problem should be resolved has been reached yet. Obesity has mostly been regarded as a matter of personal and parental responsibility. The intervention of governments usually lies in laying down normative regulations as to what constitutes a healthy diet and what food should be prepared in schools (Duramy, 2018). It has been found out that childhood obesity is more prevalent in children who have been exposed to high levels of stress and as a result suffer from behavioural issues, learning difficulties, emotional problems and somatization (Tanu et al., 2018). In the Czech Republic, the number of obese children in primary schools is on the increase. Whilst 20 years ago, only $4 \%$ of children were obese, nowadays the percentage is $14 \%$ for obesity and $25 \%$ for overweigh. The most common factors are a bad lifestyle and poor eating habits (Eurozprávy, 2008).

Intellectual disability (ID) is an umbrella term for congenital handicap of intellectual abilities which are manifested as an inability to understand and adapt to one's surroundings (Vágnerová, 2004, p. 289). Intellectual disability in an individual is seen as a limitation in intellectual functioning and adaptive behaviours (Švarcová, 2000, p. 28). According to Valenta and Müller (2003, p. 10), intellectual disability is a developmental mental disorder manifesting in lower intelligence. It is demonstrated especially as a deficit in cognitive, speech, motor and social abilities. In terms of IQ, intellectual disabilities can be divided into mild (50-69), moderate (35-49), severe (20-34) and profound (below 20), (NICM, 2014). 
Individuals with mild ID are comparable with children at the age of 9 to 12 . They can be educated at special needs primary schools. Speech is used functionally in day-to-day situations. Individuals with mild ID are able to hold a conversation and respond in a clinical interview despite the delay in speech development. Most of them manage to master self-care, i.e. eating, getting dressed, hygiene, bladder and bowel control and practical household chores.

Individuals with moderate ID are comparable with children of pre-school age, i. e. 3-6 years old. The development of cognitive and language skills is considerably delayed. Learning occurs solely on the practical level and includes mastering self-care activities and basic skills (ALFABET, 2014). Some pupils are able to attain the grounding in reading, writing and maths under the tutelage of a qualified teacher. Self-care and fine motor skills also develop with delay. Adults with moderate ID are able to carry out simple manual work under supervision. They are not able to live a life completely independent of support and instruction. This degree of disability is characteristic of noticeable differences. Some individuals attain a higher level of sensory motor skills or are capable of social interaction, for example a simple conversation, whilst others are not able to communicate their basic needs (Švarcová, 2000, pp. 28-29).

Individuals with severe intellectual disability have a considerable motor skills impairment or other associated handicaps which are characteristic of a clinically significant damage to or a defective development of the central nervous system (ALFABET, 2014). Even though education possibilities are somewhat limited, experience shows that an early and systematic expert treatment can lead to the development of motor and cognitive skills, communication skills, self-care and overall improvement in the quality of life. Nevertheless, people with severe ID remain dependent on daily supervision and support (Švarcová, 2000, p. 29).

The causes of ID may occur in prenatal, perinatal or postnatal development of an individual. In the prenatal stage (before the birth of a child), the cause could be substance abuse, undernourishment, injury, maternal infections, for example toxoplasmosis, rubella or syphilis. Smoking also constitutes a significant risk factor. In the perinatal stage (during childbirth or immediately afterwards), the cause might be prematurity, low birth weight and hypoxia. In the postnatal stage (after birth up to 2 years of age), the cause may constitute childhood infections, such as acquired meningitis and encephalitis, whooping cough, chicken pox and hepatitis. ID may also be the consequence of a head injury or drowning. Further factors leading to ID may include poverty resulting in insufficient medical care. Genetic dispositions also play an important role causing conditions such as phenylketonuria (congenital metabolic disorder) or Down syndrome (ALFABET, 2014).

People with intellectual disabilities have a shorter lifespan and a higher mortality in comparison with the general population (Bittles et al., 2002); (Patja et al., 2000). Conditions such as epilepsy, osteoporosis, motion disorders, obesity, intestinal motility disorders and hyperlipidemia are more often found in people with intellectual disabilities (Tyler et al., 2010). According to Havercamp, Scandline \& Roth (2004, pp. 418-426) and Cooper, Melville \& Morrison (2004, pp. 414-415), this population also has a worse state of health and concurrently difficult access to primary healthcare.

The school age period (6-9 years of age) is characterised by fast growth in height followed by a period of slow growth. Children are exposed to life-changing events. They start attending school and take part in different social interactions. They have to subject themselves to activities which are not necessarily perceived as attractive (schoolwork) and follow a stricter timetable. Further characteristics include cooperation, competition, accepting objective reality at face value and dependence on the leadership of parents and teachers (Vágnerová, 2000, p. 207). Early adolescence stretches between the ages of 10 and 13. It is at this stage that sexual maturation commences and in most adolescents is also completed. Cognitive processes also undergo a tumultuous development. Furthermore, psychological and social changes significantly mark this period, for example adolescents showed an increased interest in the opposite sex. Middle adolescence encompasses the ages between 14 and 16 years. Young people make a conscious effort to differentiate themselves from the adult population by adopting eccentric hairstyles, by listening to distinctive music and taking 
up idiosyncratic interests, thus seeking to connect with their peers. Searching for their identity, individuality and authenticity is also typical. In girls, the growth finishes around their 15 years of age, while in boys it continues up to 18. Late adolescence encompasses the ages between 17 and 20 years. Most adolescents are finishing their education and seek to pursue their careers. Social aspects of identity tend to gain on importance, for example the need to belong and share with others (Pavlas, 2011, pp. 56-57).

An increased body weight, which is more common in people with intellectual disabilities, is a significant risk factor for the onset of certain diseases (Melville, Hamilton, Miller \& Boyle, 2007); (Rimmer \& Yamaki, 2006). According to Melville, Hamilton, Miller \& Boyle (2007), the prevalence of obesity is $15-50 \%$ for women and 2-45\% for men (pp. 223-230). The risk of obesity appears to be especially high in women, people with Down syndrome and people with mild ID (Melville, Hamilton, Miller \& Boyle, 2007); (Hsieh, Rimmer \& Heller, 2014). Stancliffe et al. (2011) underscores the need to assess living arrangements during the obesity risk factor analysis (pp. 401-418). People living in institutional environments have the lowest prevalence of obesity and people living in their own homes experience the highest prevalence of obesity (Melville, Hamilton, Miller \& Boyle, 2007); (Stancliffe et al., 2011).

All cited authors reference to the BMI scale of the WHO. The BMI was developed as a tool for estimating the risk of disease. The higher the BMI, the higher the risk for certain medical conditions. Being overweight or obese means a higher risk of premature death, cardiovascular disease, high blood pressure, arthrosis, certain kinds of cancer and diabetes (WHO, 2018).

The goal of this study, which is part of the project Healthy Community (HC-ZAS), is to determine whether children with intellectual disabilities are prone to obesity, whether obesity is gender- and age-specific, what is the distribution of intellectual disabilities in boys and girls and whether any level of intellectual disability shows a higher proclivity to obesity.

\section{METHODOLOGY}

\section{Participants}

The study participants were pupils of Primary school for children with special needs in Otrokovice and the Special Needs and Practical School in Zlín in June 2017. In total, 53 children took part in the research. Four children were excluded from the study due to their health impairment which made them unfit for the BMI scanning.

Table 1 shows the classification of participants by age according to Pavlas (2011, p. 54). 
Tab. 1: The characteristics of participants by age

\begin{tabular}{|c|c|c|c|c|c|c|}
\hline Age group & Age & Girls & Boys & Total girls & Total boys & Average age \\
\hline \multirow{4}{*}{ School age 6-9 years } & 6 years & 0 & 0 & \multirow[t]{4}{*}{3} & \multirow[t]{4}{*}{7} & \multirow[t]{4}{*}{8.3} \\
\hline & 7 years & 0 & 1 & & & \\
\hline & 8 years & 2 & 3 & & & \\
\hline & 9 years & 1 & 3 & & & \\
\hline \multirow{4}{*}{$\begin{array}{l}\text { Early adolescence } \\
10-13 \text { years }\end{array}$} & 10 years & 1 & 3 & \multirow[t]{4}{*}{8} & \multirow[t]{4}{*}{11} & \multirow[t]{4}{*}{11.7} \\
\hline & 11 years & 2 & 1 & & & \\
\hline & 12 years & 1 & 5 & & & \\
\hline & 13 years & 4 & 2 & & & \\
\hline \multirow{3}{*}{$\begin{array}{l}\text { Middle adolescence } \\
14-16 \text { years }\end{array}$} & 14 years & 3 & 3 & \multirow[t]{3}{*}{9} & \multirow[t]{3}{*}{7} & \multirow[t]{3}{*}{15.0} \\
\hline & 15 years & 3 & 1 & & & \\
\hline & 16 years & 3 & 3 & & & \\
\hline \multirow{4}{*}{$\begin{array}{l}\text { Late adolescence } \\
17-20 \text { years }\end{array}$} & 17 years & 0 & 0 & \multirow[t]{4}{*}{3} & \multirow[t]{4}{*}{1} & \multirow[t]{4}{*}{18.8} \\
\hline & 18 years & 2 & 0 & & & \\
\hline & 19 years & 0 & 1 & & & \\
\hline & 20 years & 1 & 0 & & & \\
\hline Total & - & 23 & 26 & \multicolumn{2}{|c|}{49 children } & 13.5 \\
\hline
\end{tabular}

As can be seen from the table, participants comprise 10 school-age children, 19 pupils in early adolescence, 16 pupils in middle adolescence and 4 pupils in late adolescence. There was a total of 49 participants, 23 of whom were girls and 26 of whom constituted boys. In terms of gender, the group well-balanced. As regards age, participants ranged between 7 and 20 years old. All pupils participated with the consent of their parents. The ethical consensus was guaranteed.

Table 2 shows the distribution of ID levels within the assessed group. As can be seen, there is a slight prevalence of mild to moderate level of ID.

Tab. 2: The characteristics of participants according to the number of boys and girls in age categories and level of intellectual disabilities

\begin{tabular}{|l|c|c|c|c|c|}
\hline $\begin{array}{l}\text { The level of intel- } \\
\text { lectual } \\
\text { disabilities }\end{array}$ & $\begin{array}{c}\text { School age } \\
\mathbf{6 - 9} \text { years }\end{array}$ & $\begin{array}{c}\text { Early } \\
\text { adolescence } \\
\mathbf{1 0 - 1 3} \text { years }\end{array}$ & $\begin{array}{c}\text { Middle } \\
\text { adolescence } \\
\mathbf{1 4 - 1 6} \text { years }\end{array}$ & $\begin{array}{c}\text { Late } \\
\text { adolescence } \\
\mathbf{1 7 - 2 0} \text { years }\end{array}$ & Total \\
\hline $\begin{array}{l}\text { Mild level of } \\
\text { disabilities }\end{array}$ & 4 boys & 6 boys & 2 boys & 0 boys & $\mathbf{1 2}$ boys \\
\hline $\begin{array}{l}\text { Moderate level } \\
\text { of disabilities }\end{array}$ & 3 girl & 4 girls & 4 girls & 0 girls & $\mathbf{9}$ girls \\
\hline $\begin{array}{l}\text { Severe level of } \\
\text { disabilities }\end{array}$ & 0 boys & 5 boys & 4 boys & 0 boys & $\mathbf{1 2 ~ b o y s ~}$ \\
\hline
\end{tabular}

\section{Data collection and processing}

The InBody 230 analyser, which provides accurate results of body composition (fat, active body mass and water), was used for the detection of obesity. InBody uses the method of 8-point tactile electrodes which enable to measure the body in segments. In the picture below (Figure 1), we can see the example of the BMI scanning taken at one of the special needs primary schools. The 
data collection took place in the school's gym and was carried out within the space of two days at two different schools, one day each. Both institutions cooperated well, and the participating children looked forward to the measurement.

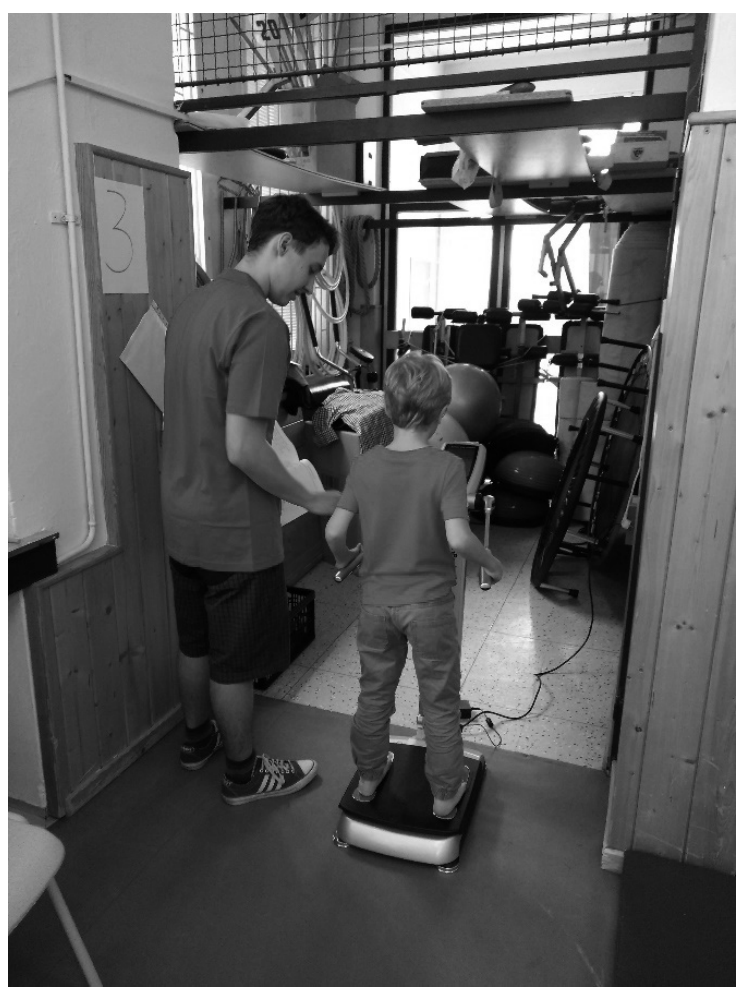

Fig. 1: BMI scanning with InBody230

BMI is an index of body weight which is commonly used to indicate underweight, normal weight and obesity. There are universal BMI ranges for the adult population which are not age- or genderspecific. However, there are no standardized ranges for children between the ages 5 and 19. In children, BMI changes with sex and age. It is calculated as for adults and then compared with z-scores and percentiles. Based on the measured BMI value, one of five categories is allotted by age and sex. The categories are as follows obesity, overweight, normal and thinness. The child then can be assigned to one of these groups (Figure 2, Figure 3). BMI is defined as a person's weight in $\mathrm{kg}$ divided by the person's height in meters $\left(\mathrm{kg} / \mathrm{m}^{2}\right)$. The ratio is expressed by the formula (WHO, 2018):

$B M I=\frac{\text { weight in kilograms }}{\text { (height in meters) }^{2}}$. 
BMI-for-age GIRLS

World Health
Organization

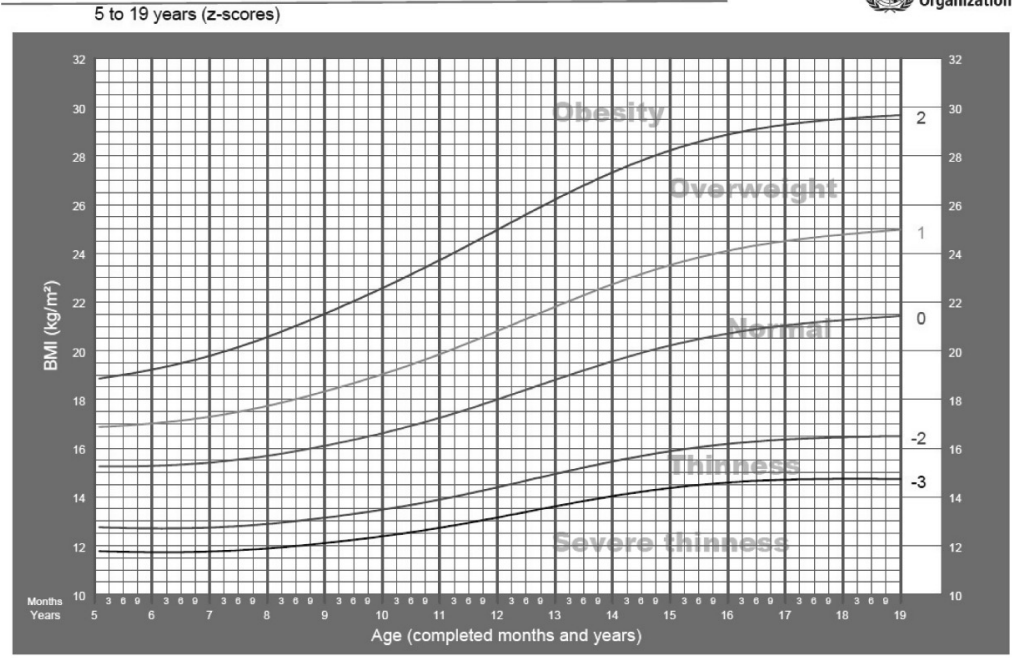

Fig. 2: Chart of BMI for age in girls

BMI-for-age BOYS

5 to 19 years (z-scores)

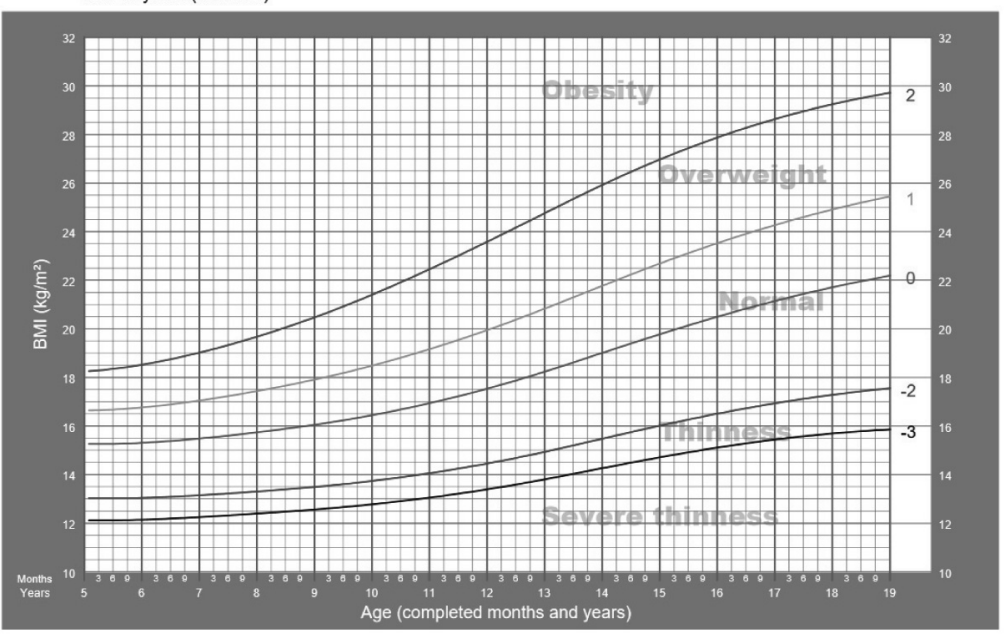

Fig. 3: Chart of BMI for age in boys 


\section{RESULTS}

The results are presented as follows:

a) BMI indicator in relation to age,

b) BMI indicator in relation to gender,

c) BMI indicator in relation to the level of intellectual disabilities.

\section{a) $\mathrm{BMI}$ indicator in relation to age}

As can be seen in Figure 4, nearly all age groups are distributed across the BMI indicators. The lowest representation can be found in underweight. Most children exhibit normal weight. The only category showing the same percentage of normal weight and obesity is early adolescence.

School-age children and early adolescents fall into underweight with $2 \%$, middle adolescents make up $4 \%$. There is no prevalence of underweight in late adolescence. Normal weight is made up by school age with $12 \%$, by early adolescence with $18 \%$, by $22 \%$ with middle adolescence and by $8 \%$ with late adolescence. Obesity is most prevalent in early adolescence with $18 \%$. School-age children and middle adolescents are represented with $6 \%$ each. There is no incidence of obesity in late adolescence.

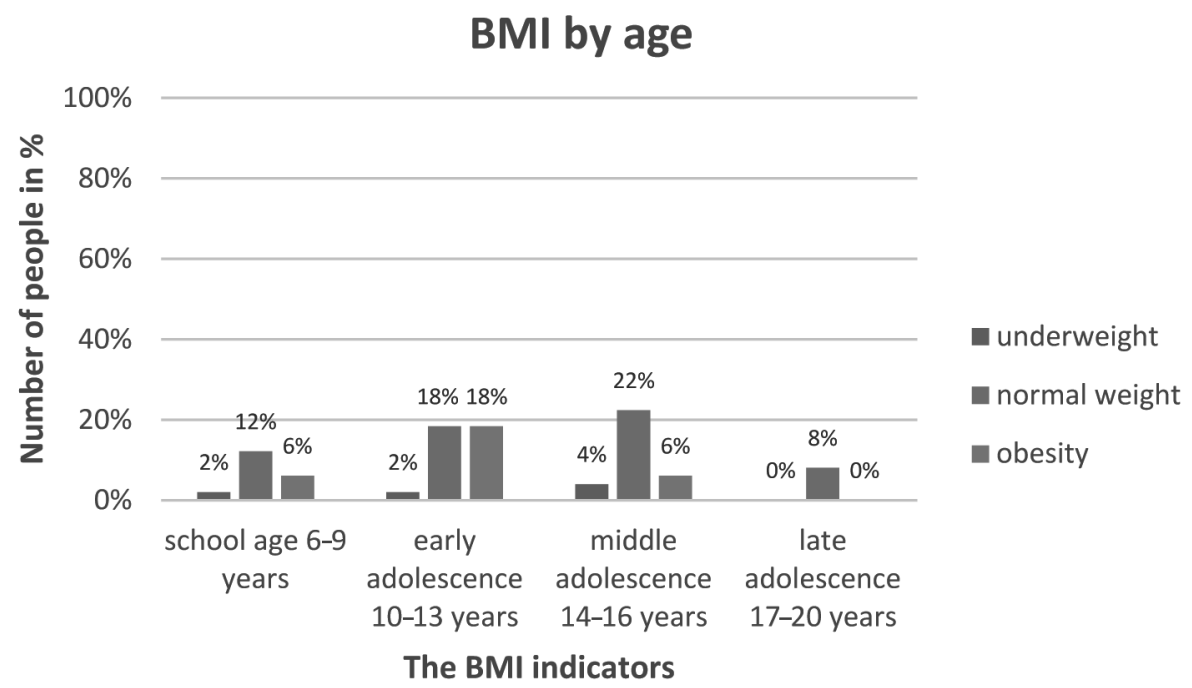

Fig. 4: BMI indicators by age

Figure 5 shows the distribution of BMI indicators within the whole group. The prevalence of obesity constitutes $31 \%$, whereas normal weight is representative of $31 \%$. Underweight occurs rarely $(8 \%)$. 


\section{BMI in the whole group}

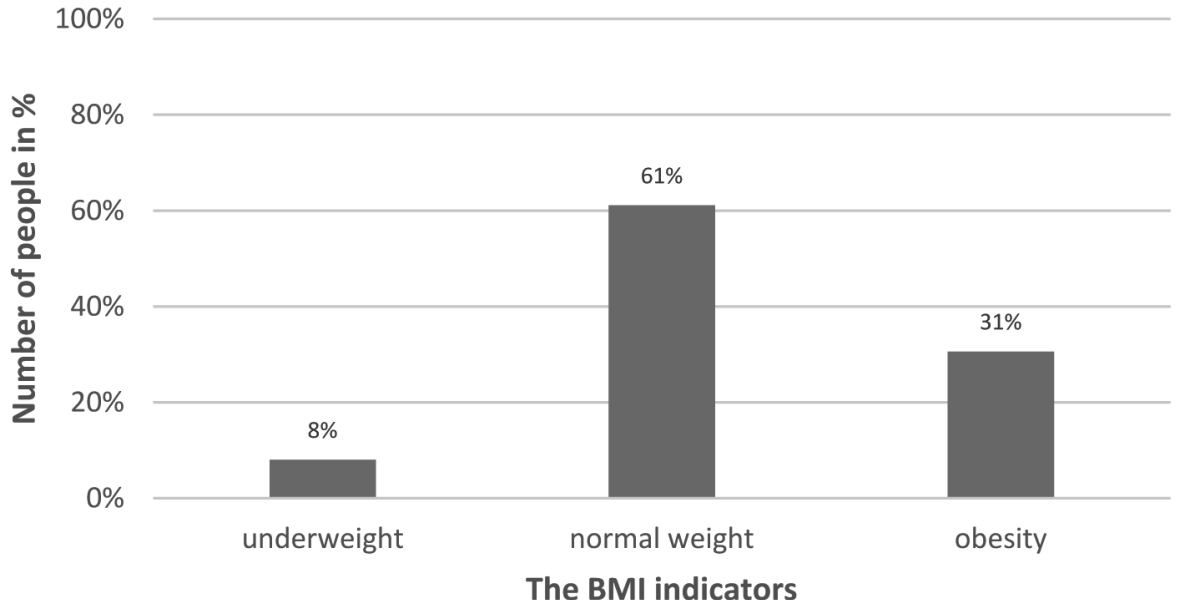

Fig. 5: BMI indicators in the whole group

\section{b) $\mathrm{BMI}$ indicators in relation to gender}

As is apparent from Figure 6 the incidence of underweight is associated with school age and middle adolescence with $14 \%$. It can be further inferred that with older age, BMI approaches normal weight.

In school-age boys both normal weight and obesity constitute $43 \%$. Early adolescence is the only category in which obesity is the most prevalent with $64 \%$, whereas normal weight is represented by $36 \%$. Middle adolescence is markedly representative of normal weight with $71 \%$. The incidence of obesity and underweight is significantly lower with only $14 \%$ for both BMI indicators. Late adolescence is represented only by normal weight.

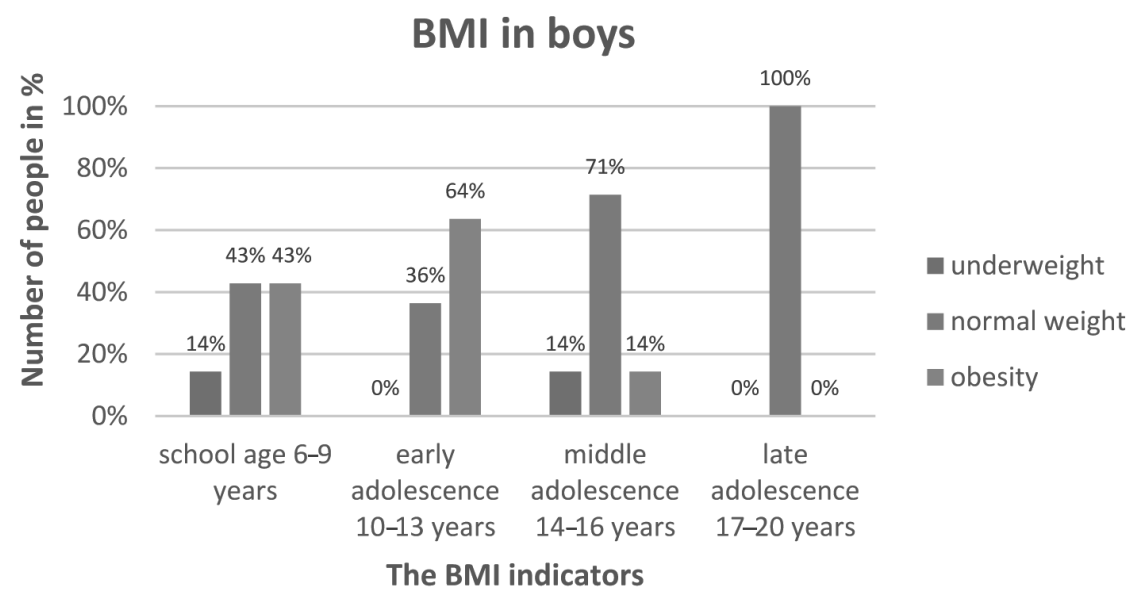

Fig. 6: BMI indicators in boys 
As can be seen from Figure 7 all age groups in girls show dominant prevalence of normal weight. All school-age girls as well as late adolescents exhibit normal weight. Obesity is associated with $25 \%$ of girls in early adolescence and $33 \%$ in middle adolescence. Underweight is represented by $13 \%$ in early adolescence and $11 \%$ in middle adolescence.

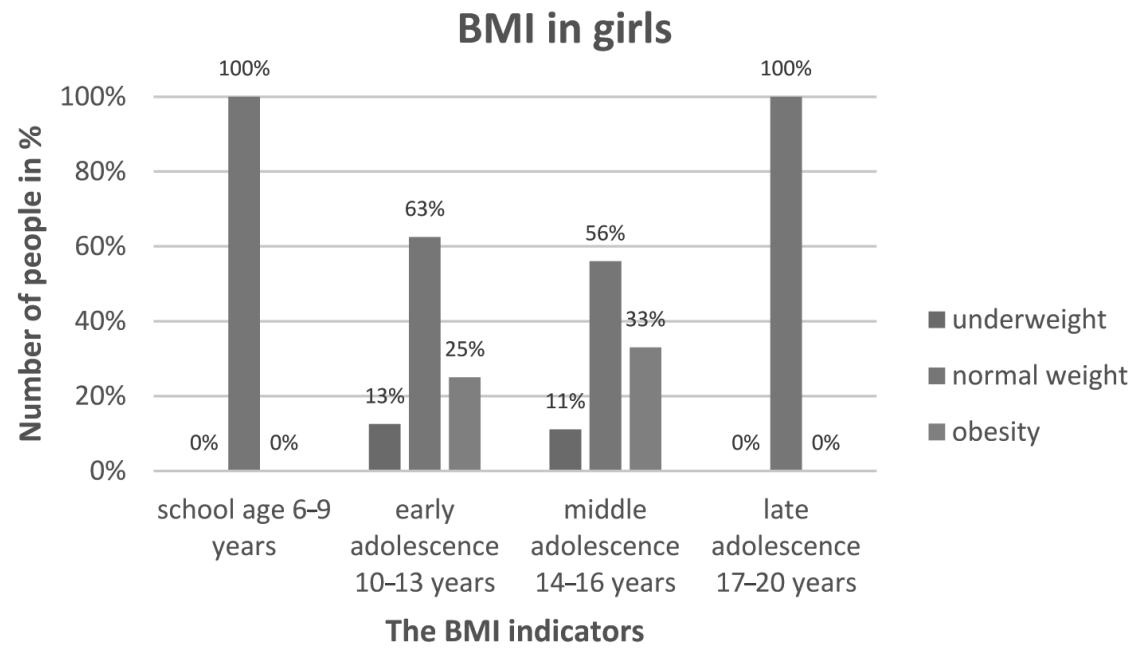

Fig. 7: BMI indicators in girls

\section{c) BMI indicators in relation to the level of intellectual disabilities}

Figure 8 shows that mild ID is distributed across three age groups. It is associated with $57 \%$ of school-age boys, $55 \%$ of boys in early adolescence and $29 \%$ of boys in middle adolescence. Moderate ID is also typical of the first three age groups and is represented by $43 \%$ of school-age boys, $46 \%$ of boys in early adolescence and $57 \%$ in middle adolescence. The incidence of severe ID in middle adolescence is as low as $14 \%$ as compared to $100 \%$ in late adolescence.

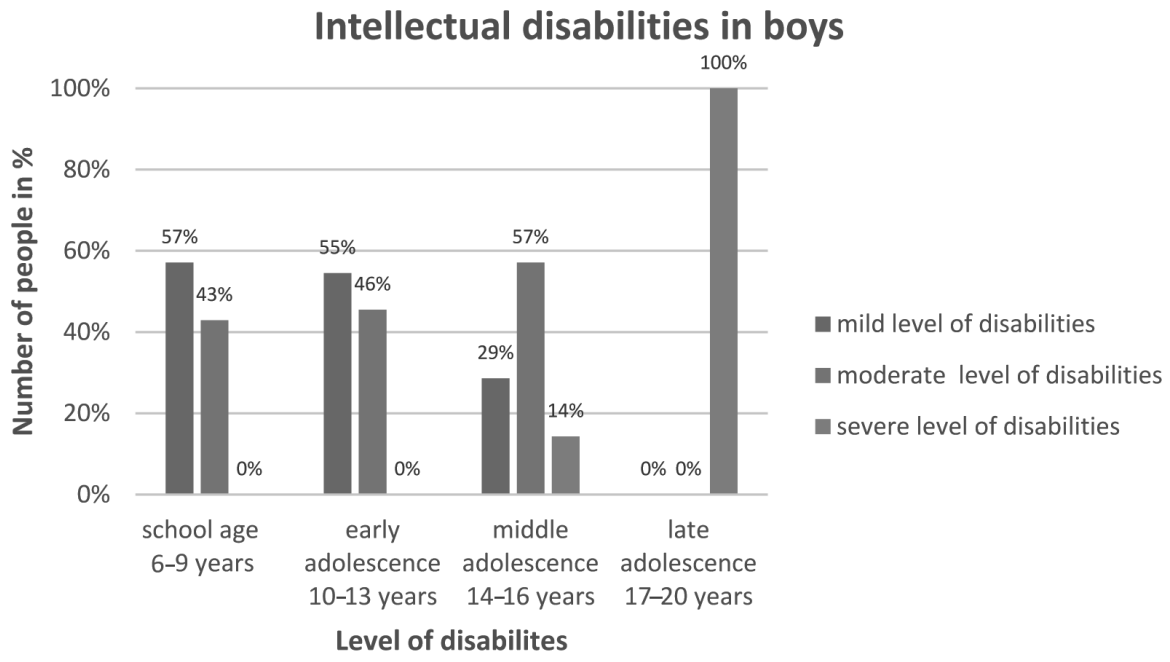

Fig. 8: ID levels in boys 
Table 3 shows mean BMI values in boys in relation to the level of their disability. Obesity is associated solely with early adolescence. It is prevalent in boys with mild as well moderate level of ID. Underweight is associated with mild ID in middle adolescence. Normal weight can be found in school-age boys with mild to moderate ID, in middle-adolescent boys with moderate and severe ID and in late-adolescent boys with severe ID.

Tab. 3: BMI values in boys by ID levels

\begin{tabular}{|c|c|c|c|c|}
\hline \multirow{2}{*}{$\begin{array}{l}\text { The level } \\
\text { of intellectual } \\
\text { disabilities in boys }\end{array}$} & \multicolumn{4}{|c|}{ Average BMI } \\
\hline & $\begin{array}{l}\text { School age } \\
\text { 6-9 years }\end{array}$ & $\begin{array}{c}\text { Early adolescence } \\
10-13 \text { years }\end{array}$ & $\begin{array}{l}\text { Middle adolescence } \\
\text { 14-16 years }\end{array}$ & $\begin{array}{c}\text { Late adolescence } \\
\text { 17-20 years }\end{array}$ \\
\hline $\begin{array}{l}\text { Mild level } \\
\text { of disabilities }\end{array}$ & 16,8 (normal) & 21,7 (obesity) & 15,3 (underweight) & - \\
\hline $\begin{array}{l}\text { Moderate level } \\
\text { of disabilities }\end{array}$ & 18,1 (normal) & 22,7 (obesity) & 22,1 (normal) & - \\
\hline $\begin{array}{l}\text { Severe level } \\
\text { of disabilities }\end{array}$ & - & - & 18,9 (normal) & 21,5 (normal) \\
\hline
\end{tabular}

As it is apparent from Figure 9 similarly to boys, obesity in girls is associated with middle adolescence, in which it constitutes $22 \%$, and late adolescence with $33 \%$. As regards ID levels, $67 \%$ of school-age girls exhibit moderate ID, whilst the remaining $33 \%$ show mild ID. Mild and moderate ID are equally distributed among girls in early adolescence with $50 \%$ respectively. Middle adolescence is made up by $45 \%$ of girls with mild ID and $33 \%$ of girls with moderate ID. Late adolescence is dominated by $68 \%$ of girls with moderate ID.

\section{Intellectual disabilities in girls}

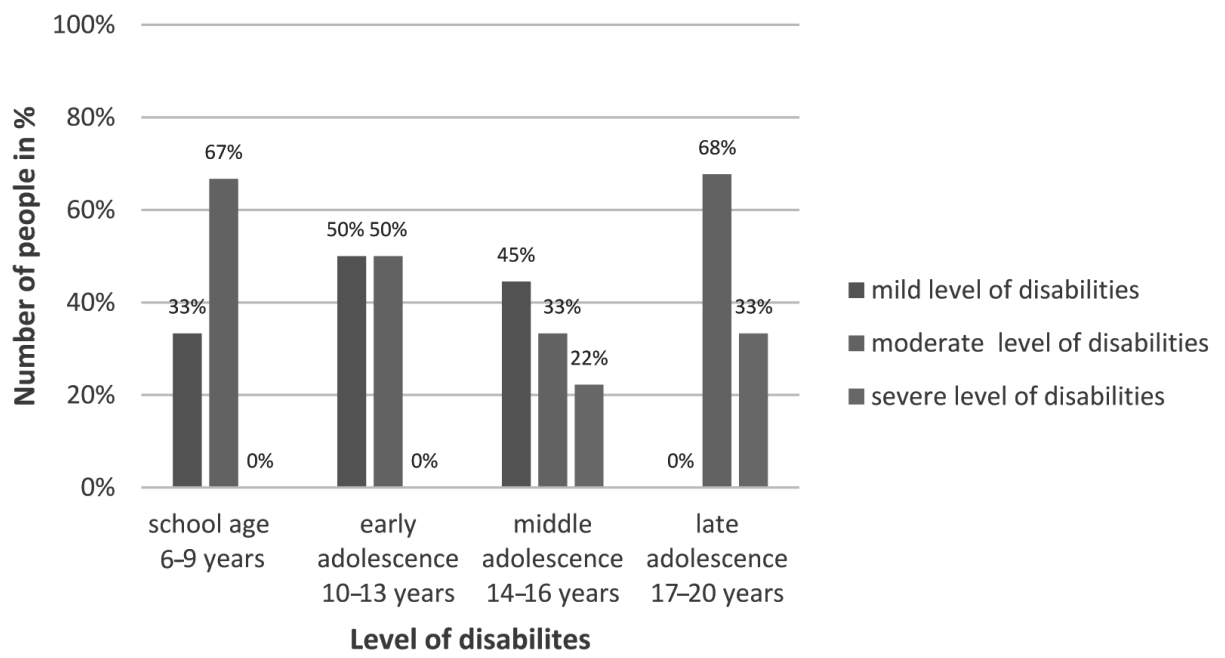

Fig. 9: ID levels in girls 
Table 4 shows mean BMI values in girls by the level of their disabilities. Normal weight is associated with all school-age girls and early-adolescent girls with mild to moderate ID. The prevalence of obesity can be found only in girls with mild ID in middle adolescence in contrast to girls with moderate and severe IDs in the same age group who fall into normal weight. Girls with moderate and severe ID in late adolescence have normal weight.

Tab. 4: BMI values in girls by ID levels

\begin{tabular}{|c|c|c|c|c|}
\hline \multirow{2}{*}{$\begin{array}{l}\text { The level } \\
\text { of intellectual } \\
\text { disabilities in girls }\end{array}$} & \multicolumn{4}{|c|}{ Average BMI } \\
\hline & $\begin{array}{l}\text { School age } \\
6-9 \text { years }\end{array}$ & $\begin{array}{c}\text { Early adolescence } \\
10-13 \text { years }\end{array}$ & $\begin{array}{l}\text { Middle adolescence } \\
\text { 14-16 years }\end{array}$ & $\begin{array}{c}\text { Late adolescence } \\
\text { 17-20 years }\end{array}$ \\
\hline $\begin{array}{l}\text { Mild level } \\
\text { of disabilities }\end{array}$ & 16,4 (normal) & 20 (normal) & 26,8 (obesity) & - \\
\hline $\begin{array}{l}\text { Moderate level } \\
\text { of disabilities }\end{array}$ & 16,9 (normal) & 20,5 (normal) & 17,8 (normal) & 23,8 (normal) \\
\hline $\begin{array}{l}\text { Severe level } \\
\text { of disabilities }\end{array}$ & - & - & 23 (normal) & 21,4 (normal) \\
\hline
\end{tabular}

\section{DISCUSSION}

It is interesting that the same findings made for adults are also valid for children with intellectual disabilities. In the adult population, many studies have determined a correlation between obesity and mild ID (Melville, Hamilton, Miller \& Boyle, 2007). Rimmer \& Yamaki (2006) have arrived at the same conclusion. We have also observed the same tendency in both genders. In boys, obesity is prevalent in early adolescence and in girls it occurs in middle adolescence and is associated with mild ID. One of the reasons why this correlation has not been identified for the same age in both genders might be the fact that girls mature 1-2 years faster than boys (Pavlas, 2011, pp. 56-57). As a result, obesity in boys with mild ID is associated with late adolescence rather than middle adolescence.

The finding that women are more prone to obesity than men (Melville, Hamilton, Miller \& Boyle, 2007), which is also supported by Hsieh, Rimmer \& Heller (2014), has not been observed in our assessed group for early adolescence, where obesity is associated with nearly $64 \%$ as compared to only $25 \%$ of girls. This significant disproportion may again be linked to the differences in development between both genders. It is possible that girls at this age seek out a more active lifestyle than boys, for example they may attend after school clubs which focus on physical exercise.

The above-mentioned argument that women have a higher proclivity to obesity than men (Melville, Hamilton, Miller \& Boyle, 2007), as also advocated by Hsieh, Rimmer \& Heller (2014), has been confirmed for middle adolescence in our research. In this category, only $14 \%$ of boys show obesity, while in girls the percentage is considerably higher (33\%). At this age, obesity is influenced by physiological differences between men and women rather than intellectual disabilities. During puberty, boys experience an increase in muscle mass caused by higher testosterone levels. In girls, estrogen causes fat build-up in the area of hips and buttocks.

The proportion of fat is considerably higher in women than men. In adulthood, women have, on average, $27 \%$ of body fat as compared to $15 \%$ of body fat in men. The percentage of visceral fat is four-fold greater in women than in men $(3 \%)$. Visceral fat protects internal organs and plays a vital part in healthy bodily processes. The amount of fat naturally increases with age in both genders $(\check{C} S O B, 2017)$. 
Despite the positive finding that there is $61 \%$ prevalence of normal weight in contrast to that of $31 \%$ of obesity in children with ID, the sad true remains that obesity is on the increase and will probably continue rising. This conclusion can be inferred from the comparison of presented findings with publicly available data on the prevalence of obesity in the general childhood population in the in the Czech Republic which shows an increase from $4 \%$ to $14 \%$ over the last twenty years and $25 \%$ of children at primary schools have overweight (Eurozprávy.cz, 2018).

According to experts, the cause of obesity lies in a bad lifestyle and poor eating habits (Eurozprávy, 2018). Considering that lunch options in school canteens are a subject of strict state regulation and supervision, the main role in childhood obesity is probably played by the family. The need to take family setting into account within the obesity risk factors analysis is also pointed out by Stancliffe et al. (2011).

\section{CONCLUSION}

In total, 49 children in the period of school-age, early adolescence, middle and late adolescence participated in the research. More than half of them have a normal weight (61\%) and proclivity to obesity have only one third ( $31 \%$ ) children.

The differences in BMI values among boys can be characterized by the fact that underweight is prevalent only at school age and middle adolescence (14\%). The most notable difference in normal weight can be identified between age groups early adolescence and middle adolescence, in which case middle adolescence shows a $35 \%$ increase. Consequently, boys in middle adolescence are estimated to exhibit lower BMI than in early adolescence, i.e. they will become slimmer. Obesity in boys is associated with early adolescence (64\%).

The differences in BMI values among girls are characteristic of the fact that underweight and obesity are only associated with early and middle adolescence. Girls in middle adolescence demonstrate a decrease in underweight by $2 \%$, in obesity by $3 \%$ and increase in normal weight by $4 \%$. There is a prevalence of normal weight in late adolescence. Consequently, it can be inferred that girls will exhibit a lower BMI value in late adolescence than they did in the previous two stages. In other words, they will become slimmer. Obesity among girls is associated with middle adolescence (33\%).

Both genders show prevalence of mild and moderate levels of ID.

In boys, obesity is associated with early adolescence and both mild as well as moderate IDs, whereas in girls, obesity is associated with middle adolescence and mild ID.

\section{References}

Bittles, A. H., Petterson, B. A., Sullivan, S. G., Hussain, R., Glasson, E. J., \& Montgomery, P. D. (2002). The influence of intellectual disability on life expectancy. The Journals of Gerontology, 57, 470-472.

Cooper, S. A., Melville, C., \& Morrison, J. (2004). People with intellectual disabilities. Journal of BMJ, 329, 414-415.

Duramy, B. F. (2018). Childhood obesity and positive obligations: a child rights-based approach. Journal of Seattle University Law, 42, 87-128.

Eurozprávy.cz (2018). Obézních dětív Česku přibývá: za 20 let jich je dvakrát tolik. Retrieved from https://eurozpravy.cz/domaci/spolecnost/235777-obeznich-deti-v-cesku-pribyva-za-20-let-jich-je-dvakrat-tolik/ (accessed December 29, 2018).

ČSOB (2017). Rozdíly mezi muži a ženami. Retrieved from https://www.csobnazdravi.cz/news/dil-4-rozdily-mezi-muzi-azenami/ (accessed January 6, 2019).

Havercamp, S. M., Scandline, D., \& Roth, M. (2004). Health disparities among adults with developmental disabilities, and adults not reporting disability in north Carolina. Journal of Public Health Reports, 119, 418-426.

Hsieh, K., Rimmer, J. H., \& Heller, T. (2014). Obesity and associated factors in adults with intellectual disability. Journal of Intellect Disabilities, 58, 851-863.

ALFABET (2014). Mentální postižení. Retrieved from https://www.alfabet.cz/informace-o-typech-zdravotniho-postizeni/ mentalni-postizeni (accessed November 11, 2018). 
Melville, C. A., Hamilton, S., Hankey, C.R., Miller, S., \& Boyle, S. (2007). The prevalence and determinations of obesity in adults with intellectual disabilities. Journal of Obesity, 8, 223-230.

NICM (2014). Klasifikace mentálního postižení. Retrieved from http://www.nicm.cz/klasifikace-mentalniho-postizeni (accessed December 29, 2018).

Patja, K., livanainen, M., Vesela, H., Oksanen, H., \& Ruoppila, I. (2000). Life expectancy of people with intellectual disability: a 35-year follow up study. Journal of Intellect Disabilities, 44, 591-599.

Pavlas, I. (2011). Výkonová motivace a interpersonální potřeby. Ostrava: Pedagogická fakulta Ostravské univerzity v Ostravě.

Rimmer, J. H., \& Yamaki, K. (2006). Obesity and intellectual disability. Journal of Mental Retardation and Developmental Disabilities Research Reviews, 12, 70-82.

Stancliffe, R. J., Lakin, K. C., Larson, S., Engler, J., Bershadsky, J., Taub, S. Fortune, J. \& Ticha, R. (2011). Overweight and obesity aboung adults with intellectual disabilities who use intellectual disability/developmental disability services in 20 U.S. The American Journal on Intellectual and Developmental Disabilities, 116, 401-418.

Švarcová, I. (2000). Mentální retardace: Vzdělávání, výchova, sociální péče. Praha: Portál.

Tanu, G., Manju, M., Rajesh, S., \& Vandana, J. (2018). Psychopathology and stress in Indian overweight and obese children: a case control study. Journal of Indian Association for Child and Adolescent Mental Health, 14, 46-59.

Tyler, C. V., Schramm, S., Karafa, M., Tang A. S., \& Jain, A. (2010). Electronic Health Record analysis of the primary care of adults with intellectual and other developmental disabilities. Journal of Policy and Practice in Intellectual Disabilities, 3, $204-210$.

Vágnerová, M. (2000). Vývojová psychologie: dětství, dospělost, stáří. Praha: Portál.

Vágnerová, M. (2004). Psychopatologie pro pomáhající profese (3rd rev. ed.). Praha: Portál.

Valenta, M., \& Müller, O. (2003). Psychopedie. Praha: Parta.

WHO (2018). Body mass index - BMI. Retrieved from http://www.euro.who.int/en/health-topics/disease-prevention/ nutrition/a-healthy-lifestyle/body-mass-index-bmi (accessed December 27, 2018). 